\title{
International media image of Russia: trends and patterns of perception
}

\author{
Ekaterina A. Repina - Marina R. Zheltukhina - Natalya A. Kovaleva - \\ Tatiana G. Popova - Conchita Garcia Caselles
}

DOI: 10.18355/XL.2018.11.02.45

\begin{abstract}
The article presents the results of the research of media image of Russia as a great power in the international political media discourse. The main method used was the content analysis of a corpus of American, British, German, French and Spanish printed media texts during the period from 2000 to the present time. Despite the fact that Russia appears today in a fundamentally new quality and the international political establishment still sees it as one of the leading world powers, its image in the foreign media is mostly negative and largely based on stereotypes of the last century. Special attention the media pays to Russian foreign policy, describing it as aggressive and based on «imperial ambitions». The consequence of all this is a rejection of Russia as an integral part of the «civilized world», as a state which is ready to share «universal values» as they are seen by the Western society.
\end{abstract}

Key words: media image, media discourse, Western media, content analysis, Russia, great power, Empire

\section{Introduction}

One of the significant factors affecting the perception of any country is its image formed by the media in the public consciousness of its audience. A post-Soviet Russia - in its contemporary and fundamentally new quality - has all the prerequisites to become an influential and respected country in the world (Rozhkov, Kismereshkin, 2008: 6). But the media discourse does not always represent exchange of courtesies, emotional support, and neutrality of the presentation of events; on the contrary, it demonstrates often aggression, negativity, verbal pressure, suggestion, etc. (Zheltukhina et al., 2017: 207-215). The image of today's Russia - both inside the country and abroad - is deformed and blurred by the countless Russian reality contradictions (Rozhkov, Kismereshkin, 2008: 6), which evoke negative emotions escalated either unconsciously or deliberately at the foreign audience.

Despite the fact that the international political establishment still sees Russia as one of the leading world powers, its media image is mostly negative and is largely based on the stereotypes of the past century. Over the past decade two images of Russia are firmly entrenched in the Western media discourse - «a strong opponent and enemy» (USSR), and «a weak and split country» that can be and should be involved in the orbit of democratic States (Russia under Boris Yeltsin).

The strengthening of Russia's position in the international arena, a sharp intensification of its foreign policy efforts, as well as the tightening of foreign policy rhetoric - all this became an unexpected and new phenomenon for the Western media. The reporters were not ready to perceive - as they themselves stated in that period «a reviving Russia». They were not ready to hear new positions, reasons, promises and goals of Russian new world policy. Since a new philosophy was not formed, mass media in its assessment of «Putin's Russia» started returning to the old clichés typical for period of Cold War: if it is strong, then there is a danger that it will again become a real rival and enemy.

\section{Theoretical research base: condition of problem's study}

The modern political media discourse is irrational and emotional and is characterized

XLinguae, Volume 11, Issue 2, April 2018, ISSN 1337-8384, eISSN 2453-711X 
by prejudgment, subjectiveness, evaluability and affective disposition. Even the texts of the news, by default purporting to be impersonal and objective, are fundamentally formulated within a certain ideological frame of interpretation (Elder, Cobb, 1983; Fiske, 1993; Zheltukhina, 2003; Repina, 2012, Garsiya-Kaseles, 2015, etc.). The informative and suggestive nature of the political media discourse is intertwined and conditioned.

Researches in the field of country imageology are mostly interdisciplinary in nature. Although conditionally it is possible to allocate a number of approaches, or directions, according to their goals and methods.

There are works dedicated to theoretical aspects of the problem of image formation (Perelygina, 2002; Kubryakova, 2008; Popova, Zaripov, 2017, etc.). Country image researches are conducted from historical-cultural positions (Kalyuzhnaya, 2006; Rozhkov, Kismereshkin, 2008, etc.), within the political psychology (Shestopal, 2002; Zaburdaeva, 2012; Derkach, Perelygina, 2006, etc.), from the standpoint of economy, management and marketing-oriented sphere (Pochepcov, 2006; Strel'cov, Sil'nickij, 2008 , etc.). Sociological researches of country image are of a practical interest and devoted to the analysis of the social factors influence upon the image formation.

Due to some researches, a country image is «a total of all descriptive, inferential, and informational beliefs about a particular country» (Martin, Eroglu, 1993: 193), the "sum of people's beliefs, ideas and impressions about a certain country» (Kotler, Haider, Rein, 1993: 141).

Analyzing a country image, we rely on the Russian psychology vision that «each thing is primary put objectively - in the objective relations of the objective world; it is - secondly - put itself as well in subjectivity, sensuality of a person and in human consciousness (in its ideal forms)» (Leont'ev, 1983: 251-261).

In recent years, there appeared a number of works devoted to the study of a country image in the context of mass media functioning. In modern studies, the media image is mostly defined either as «the set of emotional and rational views, based on the information received from media» or as «a particular image of reality presented to the mass audience by media industry» (Galinskaya, 2013: 91-94). We adhere to a narrower interpretation of this concept, namely we consider media image as «fragments of reality described in professional journalists' texts reflecting their worldview, value orientations, political preferences and psychological characteristics» (Galinskaya, 2013: 91).

In modern society mass media texts, matched by a certain way, become one of the main sources of stereotypes. Due to D. Ol'shanskij (2001), certain patterns have a very important meaning in the process of audience evaluation of social and political processes, but play both positive and negative role. W. Lippman (2004) states that pictures appeared in the press influence people's perceptions of reality, and consequently, the audience develops its own stereotypes. He says that whether right or wrong, our imagination is shaped by these pictures seen, and consequently, they lead to stereotypes that are hard to shake. Political patterns are very often almost inaccessible for audience empirical experience and therefore they are the most stable.

\section{Methodological bases and research methods}

Methodological basis of the work is the system approach including system and complex, systemic-structural and systemic-functional approaches. According to the purpose and problems of our research, we have defined methods of the analysis. In work such research procedures as hypothetical-deductive method, inductive method, descriptive and comparative methods, elements of cognitive interpretation are used. Besides, the content analysis method to identification of a corpus of American, British, German, French and Spanish printed media texts was applied.

Our study represents an attempt to trace the history of media image formation of Russia as a great power through the content analysis of a corpus of American, British, 
German, French and Spanish printed media texts for the period from 2000 to the present time (more than 5000 publications). The search for articles was carried out by keywords via Factiva. The purpose of the study is to identify key messages, trends and stereotypes in the perception of modern Russia in foreign media discourse.

\section{Results and Discussion}

After the collapse of the Soviet Union a word combination «great power» (or «leading world power») was almost excluded from the political lexicon of both Western and Russian commentators and researchers of international relations. Today, however, experts, including leading Western scientists and politicians, turn to these terms again. Five most frequently mentioned great powers - namely USA, China, India, Brazil, and Russia - are characterized by the following parameters - territory, natural resources, demography, military capacity, economy, advanced technology, science and research, education, culture, traditions, and culture to think and act globally (Shakleina, Baikov, 2014: 288-289).

\section{Example 1}

"An uncomfortable phenomenon underlies the numerous existential dilemmas facing world leaders gathered at this weekend's Munich security conference: it is the scary sight of three superpowers - the US, Russia and China - all behaving badly, all at once" (The Guardian, UK, 19.02.2017).

Despite the fact that the international political establishment still sees Russia as one of the leading world powers, its image as a great power in media (unlike, for instance, the USA) is mostly negative and perceived rather as an evidence of resurgent «imperial ambitions». Reporters consider almost any Moscow actions in the international arena through the prism of a stereotype about a new military threat from its side. It doesn't matter either it is an integration process initiated by Russia in the post-Soviet space, or a new energy policy, or a recognition of the independence of Abkhazia and South Ossetia, or its role in the settlement of the Syrian issue, etc.

In general, the attitude of Western journalists to Russia is mostly negative. Domestic and foreign policy, the economy, personalities of leading Russian politicians - all receive a critical evaluation, as a rule. Negative media image of Russia is formed mainly by materials on such topics as corruption, money laundering, lack of transparency and stability in the economy, human rights violation, lack of freedom of expression, persecution of people for political views that do not meet the views of the elite, sexual minorities oppression.

\section{Example 2}

\section{B. Porcel (Spanish journalist, writer):}

"De lo que nadie duda es de que si Putin pudiera, reconstruiría la dictadura nacionalista, que ahora sólo puede tantear" (La Vanguardia, Spain, 28.04.2005). I No one doubts that if Putin had an opportunity he would recreate a nationalist dictatorship, which he is pondering to revitalize so far.

Speaking about country specific approaches, we should mention that German and French media generally are more firendly towards Russia. Culture events, sports (until the situation with the doping scandal happened in 2015), business events are often highlighted in a positive way. 


\section{Example 3}

Th. Gomart (expert of French Institute of International Relations (IFRI):

"La Russie est à la fois un adversaire et un partenaire "Il ne peut pas y avoir de sécurité européenne sans la participation de la Russie. Mais le comportement de la Russie a remis en cause la stabilité en Europe" (Les Echos, France, 13.07.2016). I

Russia is simultaneously the enemy and the partner. Without the participation of Russia, it is impossible to ensure security in Europe. However, Russia's behavior undermines stability in Europe.

They also give a more objective picture of the relations between Russia and Germany or France respectively.

\section{Example 4}

C. Mangold (head of Eastern Committee of German Economy):

"Die "Männerfreundschaften" zwischen deutschen Kanzlern und russischen Präsidenten hätten "oftmals stabilisierende Wirkung" gehabt, sagte Mangold. Er äußerte sich überzeugt, dass Russland unter Präsident Wladimir Putin den Weg der Demokratisierung fortsetzen werde " (Spiegel, Germany, 23.06.2005). I

The "man's friendship" between German Chancellor and Russian President would have had "often stabilizing effect", said Mangold. He expressed himself persuaded that Russia will continue the way of the democratization under President Vladimir Putin.

British and American editions have a tougher position towards Russia and its activity. As far as Spanish media is concerned, they typically publish articles with a little delay in comparison with publications of the aforementioned countries, trying not to break out of the conventional trend of criticizing Russia's actions in the international arena. The content analysis of a corpus of printed media texts showed that the journalists' attitude towards Russia as during the analyzed period was not even.

From 2000 to 2005, the key proposition in media was that Russia had lost its former influence and power, but it would be difficult for it to accept this state of affairs due to its historical heritage. During this period reporters increasingly use semantically negative words reign and regime in characterizing the political course of Russia, and call its President an autocrat and a king. The journalists' opinion that Russia regrets its lost influence was strengthened in 2005 by Vladimir Putin's message to the Federal Assembly, when he characterized the Soviet Union collapse as the greatest geopolitical catastrophe of the century.

\section{Example 5}

"PRESIDENT PUTIN, a former KGB colonel, has attacked the spy trade in Russia and America for doing "a poor job" and damaging the interests of the countries it purports to serve." (The Telegraph, UK, 22.06.2001)

Within the 21st century the situation with the presidential power in Russia changes towards strengthening, however stereotypes remain in consciousness of the western audience that foreign mass media reflect: $K G B$ agent, tsar, etc.

Example 6 
"The unlikely love-in between the president-elect and a former KGB agent who built a career on hating America has spooked many US allies. And it raises serious questions - from the fate of Edward Snowden to whether GCHQ's secrets are safe". (The Guardian, UK, 20.11.2016)

"SEVENTEEN years after Vladimir Putin first became president, his grip on Russia is stronger than ever. The West, which still sees Russia in post-Soviet terms, sometimes ranks him as his country's most powerful leader since Stalin. Russians are increasingly looking to an earlier period of history. Both liberal reformers and conservative traditionalists in Moscow are talking about Mr Putin as a 21 st-century tsar.

Mr Putin has earned that title by lifting his country out of what many Russians see as the chaos in the 1990s and by making it count again in the world. Yet as the centenary of the October revolution draws near, the uncomfortable thought has surfaced that $\mathrm{Mr}$ Putin shares the tsars' weaknesses, too". (The Economist, 26.10.2017).

Thus, in connection with the Middle East tour of Russian President reporters noted that Russia was ready to regain influence in the region. On their opinion, the evidence of this is the expansion of military-technical cooperation between Russia and the Arab States, as well as the intensification of Russia's role as one of the participant in Middle East Quartet. In connection with Baku-Tbilisi-Ceyhan pipeline, commissioning experts emphasized that Kremlin's obsession to prevent the creation of oil transportation routes bypassing Russia, as well as its policy to improve control over energy, created an obstacle for Russian companies to participate in this project. Media considered Kyrgyzstan Tulip Revolution as another step towards the loss by Moscow its influence in the post-Soviet space.

\section{Example 7}

"Tampoco van bien las cosas con Uzbekistán. Su presidente, Islam Karímov, se negó a asistir el año pasado a la reunión de la $O D K B$, a cuya estructura ha terminado por no adherirse y en cuyo seno se encuentran, además de Rusia, Armenia, Kazajstán, Kirguistán y Tayikistán. Karímov reprocha a Moscú su decisión de instalar una segunda base militar en Kirguistán.

La llamada «Revolución de los tulipanes», en la primavera de 2005, enfrío las relaciones entre Kirguistán y Rusia, pero Kurmanbek Bakiyev, que emergió de aquella revuelta y fue reelegido presidente el pasado verano, ha hecho todo lo posible para ganarse la confianza y el favor de Rusia. Ahora, es uno de sus incondicionales." (ABC, Spain, 13.02.2010). /

Neither the things are fine with Uzbekistan. Its President, Islam Karimov, refused to be present last year at the meeting of the $O D K B$, at whose structure has ended up without adhering and in whose bosom they are, in addition to Russia, Armenia, Kazakhstan, Kirguistán and Tajikistan. Karimov reproaches to Moscow its decision to install the second military base in Kirguistán.

The called "Revolution of the tulips», in spring of 2005, cooled the relations between Kirguistán and Russia, but Kurmanbek Bakiyev, which emerged of that riot and President was re-elected last summer, has done all the possible to gain him the confidence and the favor of Russia. Now, he is one of its unconditional ones.

An important marker is Vladimir Putin's speech at the Munich security conference on February 10, 2007. Mass media interpreted it as Moscow transition to active actions. Newspapers noted that Russia was going to take active attempts to get back the role of a great power.

XLinguae, Volume 11, Issue 2, April 2018, ISSN 1337-8384, eISSN 2453-711X 


\section{Example 8}

"Russia is again seeking a role as a global power and is therefore flexing its muscles" (The Guardian, UK, 28.08. 2007).

The position of Russia under Vladimir Putin - which is a strong state that intends to play by its own rules - was an unexpected and new phenomenon for the Western media. While evaluating Russian activity, reporters turned to the stereotypes typical for the period of Cold War. They noted that during the reign of Vladimir Putin Russia contributed to the growth of armaments, and hence the possibility of their use in the West. Russia is characterized by such expressions as: imperial ambitions, flexing its muscles, returning to its old imperial politics, powerful reminder, etc.

A result of this perception is that any large-scale Moscow's plans get a negative evaluation in media. Moreover, such interpretation is given not only to high-profile foreign policy steps of Kremlin, such as collision with U.S. missile defense in Europe, to the resumption of long-range flights of strategic aviation. A negative interpretation is also given to such innocuous actions as an expedition to the North Pole and plans for the development of Arctic shelf, the decision of Russian Space Agency to send a mission to the moon by 2025, the celebration of the 50th anniversary of Baikonur, Victory Day Parade on Red Square on the $9^{\text {th }}$ of May, etc. The theme of struggle and confrontation with Russia is firmly fixed in the media field. Journalists believe that the West should be consolidated against, as they note, «hooligan methods» of Russia. From 2008 to 2012 (Russia under Dmitry Medvedev) a number of publications, which contain vocabulary related to the negative «imperial theme», decreased by approximately $30 \%$. In the media field there appeared articles where the hope for Russian economy and politics liberalization was expressed. However, the basic idea of media publications in this period was following: Dmitry Medvedev is more liberal than Vladimir Putin in his views on economic and political issues; however Dmitry Medvedev's reformist ideas have only verbal, but not practical implementation, as Vladimir Putin remains the only decision-maker in the country. The political system of Russia in this period is described as a well-orchestrated political spectacle.

Today journalists continue covering changes in Russia basing on the ideas developed over the last century. Special attention the media pays to Russian foreign policy, describing it as aggressive, based on «imperial ambitions», on the desire to regain the role of the a great power, and finally, as threatening international security and stability.

\section{Example 9}

"And the sidelined, victimized Russia that Mr. Putin described in 2007 is gone, replaced by a country that has forced its way back on to the world stage with the invasion of Crimea, decisive intervention in Syria and western countries' accusations of disrupting their elections" (Financial Times, 16.02.2017).

\section{Conclusion}

Assuming that «we really build, but not the World, but the Image, actively «bailing» it ... from the objective reality» (Leont'ev, 1983: 251-261), we should suppose that two images of Russia as «a great power» and as «a country which aspires to play the role of a great power», as «a resurgent Empire» - will be for long in contrast in the foreign media field.

The main conclusions can be summarized as follows:

1. The image of Russia in Western media is negative and is based on the perceptions, which were developed over the last century - the image of the enemy.

2. Russia is characterized as a resurgent/revived Empire, seeking opportunities to 
regain its lost role of a great power by all means.

3. Russia is often described as a country that «aspires to be a great power», as an Empire (negative connotation), rather than as a great power/global power (positive connotations).

4. The strengthening of Russia's role in the international arena is not denied. However, its foreign policy is characterized as aggressive, threatening for the international security and stability.

It is also possible to conclude that there is a clear possibility for the growth of Western media criticism for Russia in the coming years. In addition, the problem here is not only in nominations and evaluations, but also in real actions and real events that can be evaluated from different points of view. The consequence of all this is a rejection of Russia as an integral part of the «civilized world», as a state which is ready to share «universal values» as they are seen by the Western society.

\section{Bibliographic references}

BRITO, T. 2005. Rusia empieza a recomponer las relaciones con sus vecinos. ABC, Spain, 29.03.2005. Available online: http://www.abc.es/hemeroteca/historico-13-022010/abc/Internacional/_1133753931946.html\#

DERKACH, A.A. - PERELYGINA, E. B. 2006. Politicheskaya imidzhelogiya. Moskva: Aspekt Press. ISBN 5-7567-0416-7. ISBN 978-5-7567-0416-7.

ELDER, C.D. - COBB, R. W. 1983. The Political Uses of Symbols. N.Y.: Longman. ISBN 0582283922, 9780582283923.

FISCHER, J. 2007. Confronting Russia. The Guardian, 28.08.2007. Available online: https://www.theguardian.com/commentisfree/2007/aug/28/russiafromcooperationtoco nfrontation

FISKE, J. 1993. Television Culture. L., N.Y.: Routledge. ISBN 0-415-03934-7.

GALINSKAYA, T.N. 2013. Ponyatie mediaobraza i problema ego rekonstrukcii v sovremennoj lingvistike. In: Vestnik OGU, vol. 11, n. 160, pp. 91-94.

GARSIYA-KASELES, K. 2015. Radical, Right movement of Spanish Confederation of Autonomous Right (CEDA) in Spain in the context of political linguistics. (The early XX century). In: Science and Education. Munich, Germany, March $19^{\text {th }}-20^{\text {th }}$, 2015, pp. 235-239. ISBN 978-3-941352-21-6.

HILLE, K. 2017. Moscow resets expectations as disorder reigns in Washington. Financial Times, 16.02.2017. Available online: https://www.ft.com/content/88d9123e-f38f-11e6-8758-6876151821a6

HUBERT-RODIER J. 2016. Thomas Gomart: "Vladimir Poutine veut prendre sa revanche sur l'Occident". Les Echos, France, 13.07.2016. Available online: https://www.lesechos.fr/13/07/2016/lesechos.fr/0211124312474_thomas-gomart----vladimir-poutine-veut-prendre-sa-revanche-sur-1-occident--.htm\#

KALYUZHNAYA, E.G. 2006. Imidzh: predystoriya i kul'turologicheskoe obosnovanie fenomena. In: Izvestiya Ural'skogo gosudarstvennogo universiteta. Ser. 2, Gumanitarnye nauki, vol. 47, n. 12, pp. 45-52. ISSN 2227-2283. eISSN 25876929.

KOTLER, P. - HAIDER, D. - REIN, I. 1993. Marketing Places: Attracting Investment and Tourism to Cities, States and Nations. NY: The Free Press. ISBN 002-917596-8.

KUBRYAKOVA, E.S. 2008. K opredeleniyu ponyatiya imidzha. In: Voprosy kognitivnoj lingvistiki, n. 1, pp. 5-11. ISSN 1812-3228.

LEONT'EV, A.N. 1983. Izbrannye psihologicheskie proizvedeniya: V 2-h t. Moskva: Pedagogika. T.1. 4303000000-025. T.2. 4303000000-064

LIPPMAN, U. 2004. Obshchestvennoe mnenie. Moskva: In-t fonda «Obshchestvennoe mnenie». ISBN 5-93947-016-5 
MANGOLD, K. 2005. Deutsche Wirtschaft sorgt sich um Russland-Beziehungen. Spiegel, Germany, 23.06.2005. http://www.spiegel.de/wirtschaft/aussenhandeldeutsche-wirtschaft-sorgt-sich-um-russland-beziehungen-a-361800.html

MARTIN, M.I. - EROGLU, S. 1993. Measuring a Multi-Dimensional Construct: Country Image. In: Journal of Business Research, vol. 28, n. 3, pp. 191-210. ISSN 0148-2963

OL'SHANSKIJ, D.V. 2001. Osnovy politicheskoj psihologii. Ekaterinburg: Delovaya kniga. ISBN 5-88687-098-9

PERELYGINA, E.B. 2002. Psihologiya imidzha: ucheb. posobie. Moskva: Aspekt Press. ISBN 978-5-7567-0265-2.

POCHEPCOV, G.G. 2006. Imidzhelogiya. Moskva: «Refl-buk»; K.: «Vakler». ISBN 5-87983-096-9, 966-543-061-0, 966-543-048-3.

POPOVA T.G. - ZARIPOV R.I. 2017. Osobennosti metaforicheskoj reprezentacii obraza Rossii v zapadnyh SMI. In: Politicheskaya lingvistika, vol. 5, n. 65, pp. 49-56. ISSN 1999-2629.

PORCEL, B. 2005. Catastrofes nacionales. La Vanguardia, Spain, 28.04.2005.

REPINA, E. A. 2012. Politicheskij tekst: psiholingvisticheskij analiz vozdejstviya na ehlektorat. Moskva: INFRA-M. ISBN 978-5-16-005215-1.

ROZHKOV, I. - KISMERESHKIN, V. 2008. Imidzh Rossii. Resursy. Opyt. Prioritety. Moskva: RIPOL klassik. ISBN 978-5-386-01027-0

Russia under Vladimir Putin. A tsar is born. 2017. In: The Economist, 26.10.2017, Available online: https://www.economist.com/news/leaders/21730645-world-markscentenary-october-revolution-russia-once-again-under-rule

SHAKLEINA, T.A. - BAIKOV, A.A. 2014. Megatrendy: Osnovnye traektorii ehvolyucii mirovogo poryadka v XXI veke. 2-e izd., ispr. i dop. Moskva: Aspekt Press. ISBN 978-5-7567-0768-7

SHESTOPAL, E.B. 2002. Politicheskaya psihologiya: Uchebnik dlya vuzov. Moskva: INFRA-M, 2002. (Seriya «Vysshee obrazovanie»). ISBN 5-16-000981-7.

STREL'COV, D. V., SIL'NICKIJ, A. A. 2008. Politika YAponii po prodvizheniyu nacional'nogo i regional'nyh brendov. In: Korporativnaya imidzheologiya, vol. 1, n. 02, pp. 7-12. ISSN 1997-5937.

The new special relationship: what does Putin want from Trump? 2016. In: The Guardian, 20.11.2016, Available online: https://www.theguardian.com/usnews/2016/nov/20/new-special-relationship-what-does-putin-want-from-trump-kgb

TISDALL, S. 2017. Munich conference: three dangerous superpowers - and we're stuck in the middle. In: The Guardian, UK, 19.02.2017. Available online: https://www.theguardian.com/commentisfree/2017/feb/19/munich-security-

conference-nato-trump-russia-china-superpowers-europe-pig-in-middle

WARREN, M. 2001. Spies doing a bad job, says former KGB man Putin. In: The Telegraph, 22.06.2001. Available online: http://www.telegraph.co.uk/news/worldnews/europe/russia/1312371/Spies-doing-abad-job-says-former-KGB-man-Putin.html

ZABURDAEVA E.V. 2012. Politicheskaya kampaniya. Strategii i tekhnologii: Uchebnik. Moskva: Aspekt Press. ISBN 978-5-7567-0647-5.

ZHELTUKHINA, M.R. 2003. Tropologicheskaya suggestivnost' massmedial'nogo diskursa: o specifike rechevogo vozdejstviya tropov v yazyke SMI. Moskva Volgograd: IYA RAN, VF MUPK. ISBN 5-88234-568-5.

ZHELTUKHINA, M.R. - BIRYUKOVA, E.V. - GERASIMOVA, S.A. - REPINA, E.A. - KLYOSTER, A.M. - KOMLEVA, L.A. 2017. Modern Media Advertising: Effective Directions of Influence in Business and Political Communication. In: Man in India, vol. 97, n. 14, pp. 207-215. ISSN: 0025-1569.

ZHEREBILO, T.V. 2017. Integrative onomastic space of a regional variant of the Russian language under conditions of bilingualism. In: Novosibirsk State Pedagogical University Bulletin. vol. 7, n. 2, pp. 111-128 
Words: 4128

Characters: 28389 (15,83 standard pages)

Associate Prof. Ekaterina A. Repina, PhD.

Faculty of Communications, Media and Design

Higher School of Economics

20 Myasnitskaya

101000 Moscow

Russia

repina69@mail.ru

Prof. Marina R. Zheltukhina, DrSc.

Institute for Foreign Languages

Volgograd State Socio-Pedagogical University

27 Lenin Prospect

400066 Volgograd

Russia

zzmr@mail.ru

Prof. Natalya A. Kovaleva, DrSc.

Institute of Law and National Security

Russian Presidential Academy of National Economy and Public Administration 84/2,

6 Vernadsky Prospect

119606 Moscow

Russia

kna13@yandex.ru

Prof. Tatyana G. Popova, DrSc.

Faculty of Foreign Languages

Military University of the Ministry of Defense of the Russian Federation

4 B. Sadovaya

123001 Moscow

Russia

tatyana_27@mail.ru

Associate Prof. Conchita García Caselles, PhD.

Faculty of Philology

Peoples' Friendship University of Russia

10/2 Mikluho-Maclay

117198 Moscow

Russia

konchitag@mail.ru 